\author{
Abstracta Iranica \\ Abstracta Iranica Revue bibliographique pour le domaine irano-aryen \\ Volume 32-33 | 2013 \\ Comptes rendus des publications de 2009-2010
}

\title{
Delio V. Proverbio. Turcica Vaticana
}

\section{Angelo-Michele Piemontese}

\section{(2) OpenEdition}

\section{Journals}

\section{Édition électronique}

URL : http://journals.openedition.org/abstractairanica/40965

DOI : 10.4000/abstractairanica.40965

ISSN : 1961-960X

Éditeur :

CNRS (UMR 7528 Mondes iraniens et indiens), Éditions de l'IFRI

Édition imprimée

Date de publication : 1 décembre 2013

ISSN : 0240-8910

\section{Référence électronique}

Angelo-Michele Piemontese, "Delio V. Proverbio. Turcica Vaticana », Abstracta Iranica [En ligne], Volume 32-33 | 2013, document 432, mis en ligne le 01 juillet 2016, consulté le 28 septembre 2020. URL : http://journals.openedition.org/abstractairanica/40965 ; DOI : https://doi.org/10.4000/ abstractairanica.40965

Ce document a été généré automatiquement le 28 septembre 2020.

Tous droits réservés 


\title{
Delio V. Proverbio. Turcica Vaticana
}

\author{
Angelo-Michele Piemontese
}

\section{RÉFÉRENCE}

Delio V. Proverbio. Turcica Vaticana. Città del Vaticano, Biblioteca Apostolica Vaticana, 2010, 270 p., 13 planches (Studi e Testi, 461).

1 L'A., conservateur des manuscrits orientaux à la Bibliothèque Vaticane et fin connaisseur de la paléographie et de la codicologie relatives à maints domaines, disserte de plusieurs sujets qui concernent la littérature turque et "turkique". Il renseigne sur tous les fonds Vaticans des manuscrits turcs (p. 23-39) et en analyse quatre lesquels étaient jusqu'ici inconnus. La collection de ces textes avec les données de manuscrits différents et l'extension de la bibliographie de sources, de traductions et d'éditions, impliquent parfois des traits qui ressortent de l'interrelation avec la littérature persane. L'étude sur le ms. Barberini Or. 165 (ff. 26r-33v), contenant le fragment d'une traduction consécutive (non interlinéaire) du Golestān de Sa'dī (chap. I, hik. 18-24), montre la façon de sonder un texte bilingue persano-turc « in sinossi interconsequenziale» (p. 45-50). Les exposés sur le Battyār-nāme en version turque (p. 51-67) et sur l'histoire des Qrq Vezîr (pers. Čihil Vazir, p. 69-118) sont aussi considérables. Ensuite la comparaison de quelques passages textuels touche le Bayțār-nāma (p. 120), le Marzbān-nāma, le Kìmiyā al-sa'ādat de Ġazzālī (p. 127-128), le tafsìr de Sūrābādī (p. 150) et l'importance de gloses persanes (p. 148-150). Salmān al-Fārisī figure en tant que "prince de Ğindās” (p. 145), probable dérivatif de Ğundāsābūr, la célèbre ville en Perse sasanide. Dans l'unique version turque-osmanlı de la bimillénaire légende du sage Ahiqar, Haykar adresse son andarz à Nādān, le jeune personnage qui est désigné par ce nom persan ou surnom emblématique d'Ignorant : 'l'Ignare' (p. 210-218). Ainsi, le livre Turcica Vaticana concerne à certains égards la littérature persane comparée sur la base de sources manuscrites. 


\section{AUTEURS}

ANGELO-MICHELE PIEMONTESE

Università la Sapienza, Rome 